\title{
Cloud Storage: Cloud Computing and Social Media to utilizing Selective Dissemination of Information Service
}

\author{
Othman Atta Ismail \\ The General Secretariat of the Central Library \\ Al -Iraqia University
}

\begin{abstract}
This paper touched upon cloud computing, their technologies and social media to provide selective dissemination of information service for the research community and the beneficiaries. It identifies the concept of cloud computing and its advantages and services offered in the field of libraries and information. It also identifies the concept of social media. The paper Builds a digital warehouse and makes digital book link available on social media to serve researchers and beneficiaries and to meet their demands and needs.
\end{abstract}

Keyword:- Cloud Computing, Social Media, Information Technology, selective dissemination of information service and Cloud storage. 


\section{Introduction}

With the continuous development in the field of modern technologies and service applications available to beneficiaries on the Internet and the emergence of web 2.0 and web 3.0 and with the cloud computing services which lead to interaction with the beneficiaries, many information institutions and University libraries have moved to access applications for use through the World Wide Web Internet. This will make most of these technologies and applications available matter that will save costs and make available information services to the largest sector of the beneficiaries they also provide the beneficiaries, information institutions and libraries the possibility of storing, processing, transmitting and sharing data anywhere and at any time Without the need to use a personal computer. All these procedures are accomplished through external devices and servers available on the Internet and cloud computing. This will ensure the security of the data and keep them from abuses, loss and damage. Thus, this study uploads digital sources for the university libraries across these servers, or the so-called cloud computing. The aim is to preserve them, and to apply the selective dissemination of information service which send digital resources and information based on the interests and tendencies of beneficiaries across social media. This service can also respond to the queries of the beneficiaries. The study consisted of four sections. The first section gave the general framework of the study. The second section dealt with the theoretical side to identify the cloud computing, its applications and services in the field of university libraries, and it recognized the concept of social media and the selective dissemination of information service. The third section offered the practical side by making available the selective dissemination of information service via social media to beneficiaries and by uploading the digital resources of cloud computing across (Google drive). And taking advantage of its features in saving retrieving data. ${ }^{1}$

\section{Web2}

Web 2: - The web is an important transition in the history of the web. Which is to move from the concept of traditional sites, whose substantive content depends on production of the site management to the concept of integrated applications, which provides a range of interactive services accessible to the user and which develops its performance to serve as a product and consumer of the substantive content of different forms. Web 2 can be seen as a network of applications and interactive social services are more than just a set of sites and the content that is mainly available depends on the subscribers. 2

\section{Web3}

Web3 :- It is also called semantic web. It is one of the concepts that emerged in the contemporary stage within what emerged from the digital environment if it is a concept it' $s$ back to working on converting the web from just a huge repository a huge amount of text, images, clips and other information that is invisible and unorganized makes it easier to take advantage of it, to a digital Warehouse or a large database linked to the information contained within the links based on understanding the meanings and relationships that make their interconnection very good information. ${ }^{3}$

\section{The first sections \\ General framework for study (1.1) The problem of the study}

The problem of the study launched in answer to inquiries following:

1. What are the advantages offered by cloud computing applications in the field of university libraries and Information institutions?

2. What are the services that can be offered to the Beneficiaries community via social media and increased interaction with the beneficiaries?

3. What are the applications that are working to build a Digital warehouse to save digital sources? 


\section{(1.2) The importance of the study}

The importance of the study appear from the importance of applications of modern techniques and applications Internet, which leads to interaction with the beneficiaries and answer to the inquiries of beneficiaries and meet their demands by providing digital resources and information according to the tendencies and concerns of beneficiaries across social media and apply the selective dissemination of information service and benefit from the advantages of cloud computing.

\section{Perhaps the justification put forward} for this technology is:

* Those features are unique to cloud computing technology In terms of saving costs with access to the services and applications efficiently and quickly.

* Advantages of cloud computing are to be used wherever the user wants, at home, at work, in the car, and in any place where there is Internet.

* Digital sources are keeping from damage and loss of.

\section{(1.3) Objectives of the study}

1. Recognize the advantages of cloud computing and its services in the field of university libraries.

2. Availability of digital resources for Beneficiaries community via the Internet, according to their demands.

3. Apply the selective dissemination of information service for Beneficiaries community and to increase interaction between beneficiaries and university libraries.

4. Continuous communication with beneficiaries via social media and informed there with what is new in the library.

\section{(1.4) Research Methodology}

Researcher used practical approach to apply cloud computing technology, its applications, its software and how to utilize them in the field of libraries to offer the selective dissemination of information service via social media.

\section{(1.5) The study procedures}

1. The resources are converting from of the paper form (Hard paper) to digital form (software copy).

2. Apply the selective dissemination of information service

3. Digital Warehouse Building by Using Google Drive Program.

4. The use of Facebook as a media to inform beneficiaries.

\section{(1.6) Search limits}

The spatial border: Baghdad.

The temporal borders: 2015 -2016.

The objective limits: Cloud Computing social media - the selective dissemination of information service.

\section{(2.1) Cloud storage}

\section{The second Section}

\section{Theoretical Side}

Cloud storage can be defined as: It is a model for storage on the Internet where data is stored on multiple virtual servers, instead of being hosted on a specific server. It is usually provided by a third party like major hosting companies that have advanced data centers. It rents cloud storage space to its customers to suit their needs. The most popular service providers like DropBox, Amazon, Google Drive, OneDrive, MEGA, My CloudAp. ${ }^{4}$

\section{(2.2) Cloud Computing}

Cloud Computing can be defined as:It is a technology that depends on the transfer of processing and storage space for computer to Cloud, It maid devices group like servers is accessed via the Internet. Thus, the information technology program will turn from products into services. The infrastructure for cloud computing depend on the Advanced data centers which offers large storage space for users it also provide some programs as services to users. It relies on the possibilities provided by Web 2.0 technologies. This can be illustrated in Figure (19). ${ }^{5}$ 
Cloud Computing can also be defined as: Network services provides a cheap and guaranteed on-demand platforms these are accessible and easy-to-use ways. ${ }^{6}$

Cloud computing is not a new technique, but it is a new service and to understand that we must put a simplified definition of cloud computing say that cloud computing is you are using a computerized sources (Hardware, software) Via the Internet introduction to you in the form of service A. You do not care about the manner in which it operates, these and how to operate it, or how it communicated to each other and how to set up a network among themselves and the software installed

\section{(2.3) Advantages of cloud computing}

Cloud computing works that the user gets a service that allows him to store all of his data outside the scope of his personal device (personal computer) that is he stores his files and his data on cloud computing servers as Image files, he can access them from anywhere where there is an Internet connection available, Why all this trouble? What's the Damage in storing files locally on the personal computer instead of uploading files to the Internet and downloaded each time a user need it?.

\section{The fact that the advantages here are difficult to be counted, but some of them are:}

1. The user can be reached by to his files and his data that he stored from anywhere where the his files are stored entirely online (Internet) and he does not need because accompanied personal device ( personal computer) length of time to bring it up to his files are what we do than storing some files to the email in the form of attachments so that we can access them from anywhere where there is a computer and Internet connection, but of course more fully where the user stores all the files and not some On the internet.
2. In this way the user does not require a specific operating system or a specific browser the accesses to the his files and stored and used as the files are available to him without restrictions on the operating system and the type of files, the user can to participate files with an unlimited number of users it is that allows specific users that they reach specific of its files that the user can only be determined but not every user needs a separate file copy, they all share the same file, which reduces the storage space consumption.

3. Storage space consumption does not be a big for example, a music production company will make available the music file one time, while millions of users can be Reach to the same file without needing because each of them takes a separate copy of the file. ${ }^{8}$

4. Access data and applications from anywhere where internet service is available.

5. Low cost of the physical equipment (Hardware).

6. It will enrich the user (individual / company) university libraries and information centers to purchase software licenses.

7. Institutions, companies, university, libraries, and information centers do not need to allocate a place for devices that manage work.

8. No need for technical support within the facility, university libraries and information centers.

9. You can depend on her in large and the complex research Which saves time.

10. Save and backup those serves the user, especially programmers.

11. Property share files to reduce storage space.

12. Sizing or link cost using Scalability. ${ }^{9}$ 


\section{(2.4) Compare traditional computing with cloud computing}

Cloud computing allows you to access all of your applications and services from anywhere, anytime via the Internet, because the information is not stored on your hard drive but on the servers (the company service providers).

Reduced costs for companies, where it is no longer necessary to buy faster computers and the best in terms of memory or above in terms of hard drive space, But any device can be a normal personal computer(PC)by using any Web browser to access cloud services used by the company (edit documents, store files, edit images, ..., etc). As the companies and the university libraries and information centers are no longer, buy expensive equipments, such as expensive services to offer e-mail service for its employees, or large storage units to work backups of data and information for the company and the university libraries and information centers. ${ }^{10}$

Ensure the service works permanently, where the company is committed to the introduction of cloud storage service makes sure that the service is working around the clock in the best possible way. When you use a cloud storage service, the information stored on more than one server to ensure no loss, the company also offered the service is committed to fix any glitches or breakdowns emergency as fast as possible. This saves you a lot of time and cost as a user or owner of the company and the university libraries and information centers is responsible for its equipment and software for the management, take advantage of the large infrastructure offered by cloud services to do the tests and scientific experiments. Some complex calculations take years to conducting or processing ordinary computers, while companies such as Google and Amazon allows his cloud consisting of thousands of servers associated with each other to perform such calculations in record time. ${ }^{11}$

\section{(2.5) Cloud computing services in the field of libraries and information center}

Cloud computing allows for the beneficiaries and information centers and university libraries to store data across servers and servers via the Internet outside the scope of the personal device or personal computer or mobile device or laptop any computer where they can retrieve data from anywhere and at any time, provided that there is internet connection as well as the make it available at the same time for more than a beneficiary this service is called in libraries save and automatic retrieval service. Where data are stored in digital form (software copy) and Retrieval a computerized, by processing the data in electronic Where the resources can be sent by the interests of the beneficiaries is called selective dissemination of information service, by sending resources in electronic form will be applied Borrow books electronic service by ordering the beneficiaries of digital resources (software copy) and according to their needs and from this standpoint, according to this concept can be applied to following service:

1. Electronic book loan service (here to get a copy of the resources without the need to return it).

2. Software as a service (Saas) ${ }^{12}$ in the field of libraries.

3. Save service and automatic retrieval service.

4. Selective dissemination of information service.

\section{(2.6) The concept of Social media}

Social media can be defined as: It simply:Techniques exist on the Internet used by people, to communicate, and interact with each other,. the term "social media" has developed to happen great fanfare, it includes all electronic communication tools existing during twenty-one century, some people use social media is a wider, to describe all types of cultural phenomena that involve communicating, and not only communicating techniques, all too often, for instance, people use the word social media to describe the user-generated content, or content submit by users, it is the content that users typed, publish and share it by using electronic publishing tools. ${ }^{13}$ 
It must be noted that most forms of social media, electronic; it allows users to communicate and interact with each other using computers, smart phones and the Internet. Social networks such as Facebook, Twitter. it is considered to be part of or one of the types of social media. ${ }^{14}$

As for the concept of social media: social media sites are the Web sites that users can participate and contribute to the creation or add pages and easily. $^{15}$

\section{(2.7) Social networking (Social media) components}

Social networking and tools for social networking generally consist of multiple applications or sites are most important:

1. Electronic media sites (Social media): Sites that allow people to create pages and communicate with their friends and acquaintances, such as website (MySpace) and (Facebook). ${ }^{16}$

2. Blogs: Blogs are websites that represent personal journals or personal newspapers from which the personal thoughts of individuals or groups are reported, and Blogs are open to all.

3. Electronic forums (Online forums): It sites Provides areas or spaces electronic to express their opinion and writing public topics, it is usually about a specific topic, any for each forum Particular specialty, and it is one of the most prevalent social media, 's easy to sign up(participate) and do not require a great technique to give (impart) the subject as in blogs. ${ }^{17}$

\section{(2.8) Facebook and its features}

Considered a site Facebook to social communication is Best those sites, it is more than contributed to spreading the culture of social communication between classes, caste, trends and religions around the world, and because of its characteristics we will discuss and that facilitated people to sign up and communicate On his way (through him). ${ }^{18}$
The Facebook: It is the site of social media, Meaning it is allowing for a way for ordinary people and legal persons (such as companies) that brings out (accentuates) himself, and enhance his place through the website tools for communication with other people within the scope of that site or through communication with other sites, create links to communicate with others. $^{19}$

This site was founded by Mark Zuckerberg in 2004 for the purpose of communication between students in the Harvard University, US, and then spread its use among other college students in the United States, Britain, Canada, to develops the site characteristics than just a site to highlight the personal self and images, to a specialized site in communion sponsored by Facebook company, which became billions in 2007 as a result of the involvement of 21 million subscribers in this site this year to exceed any site Social media and become the first in worldwide. ${ }^{20}$

The site has been transformed from just a place to display personal photos and communicating with friends and family, to the channel of communication between Electronic communities, and rostrum to display political ideas, and configure political groupings electronic and fail her mightiest the actual parties on the ground, as well as to become an essential Communication channel for marketing adopted by the thousands of large and small companies to connect with their audience, as well as newspapers that depended on Electronic communities to transfer her news and promotion of the her book and other media. A exceed Facebook site his the Social Function, to the communication Site multi-Purpose, it is expected that the number of subscribers in 2013, arrives nearly half a billion subscribers, In the future, to become the largest electronic gathering on earth.

\section{(2.9) Selective dissemination of information Service on social media}

Selective dissemination of information ("SDI") is a system of information systems services leads to provide beneficiaries with information that their interest in electronic form and orderly. ${ }^{21}$

Selective dissemination of information can also be defind as:It is information selected serve a certain segment of beneficiaries reflects the concerns of beneficiaries, 
It aims to provide each beneficiary periodically every week or every fortnight (Semimonthly) in information or policies that fall within the scope of his interest without asking for his part. ${ }^{22}$

It uses the concept of selective transmission of information often to describe was Built a system on the idea of the scientist Hans-Peter Lohan, and that lead to the use of electronic computers in the match the terms that express the concerns of each researcher terms that express the contents of the resourcesof the newly added to the library collections, notice beneficiary with the necessary information from these resources either send Abstract, Brief for each resource or send the entire resources. $^{23}$

\section{(2.10) Selective transmission of information service requirements}

Selective transmission of information service consists of the following components:

1. Beneficiaries files: These files include the complete information on the beneficiaries of the system Such as name, Address, the scientific degree, job, scientific background, the subject of specialization, previous experience, the areas of scientific interest, Research projects and study projects.

2. documents files: This file contains complete bibliographic information about the documents entering the system as well as descriptors or terms that reflect the subjects of these documents and are used to retrieve it.

3. Matching (the emulation): Where the terms in the file of documents are matched in the file of beneficiaries to select those documents of interest to their demands beneficiaries.

4. Notification: Where to send information on these documents to the beneficiaries of matching their demands, their needs and their interests either by postal mail or telephone or e-mail or Social Media.

5. Files update: By asking, the beneficiary evaluation of the documents received in order to be possible to describe needs better by adding and modifying. ${ }^{24}$

\section{The third Section \\ Practical side \\ (3.1) Selective transmission information service is a applying by Cloud computing applications and Social Media}

The selective transmission information service is applying by Cloud computing applications and Social Media, through several phases, as follows: First: - Information resources is Converting from hard copy form to digital format (software copy) by using the scanner, according to the needs of beneficiaries. As shown in Figure (1) in Appendix (1).

Second: - Assembling Images taken in the previous step of the thesis or $\mathrm{PhD}$ thesis or book into one document (pdf) by using Adobe Acrobat 7.0 Professional Program. As shown in Figure (2) in Appendix (1).

Third: - File compression or reduce its size, there are several options the simplest to do it. It is the Feature existing in Adobe Acrobat 7.0 Professional Program, it is option Reduce file size to reduce the size for the purpose of uploaded where it is reduced in size to a quarter. As shown in Figure (3) in Appendix (1).

Fourth: - We do the Name of the file according to Name of title the thesis or book (title of information resource).

Fifth: - Creation of Gmail Mail in order to be uploading files for digital warehouse.

Sixth: - Open the Gmail Mail. As shown in Figure (4) in Appendix (1).

Seventh: - Creation of a digital warehouse. As shown in Figure (5) in Appendix (1). Where be upload to him digital resources. And it is used for applying cloud computing (Google drive).

Google drive: It is a cloud storage service offered by Google Inc. Provide free storage space of $15 \mathrm{~GB}$

As well as the advantages enjoyed by as follows:

1. Connectivity with Gmail Mail: Google Drive application allows you to send files sizes infinite (As, of course, does not exceed the maximum storage space) by Gmail mail directly from within the application itself, and without the need to go to Gmail Mail. 
2. The synchronization with your personal device: Google Drive application that allows other enormous feature, it is the synchronization your personal device with files account and Google Drive, which allows you to create new files or amendment to existing files, even without an Internet connection, that these amendments transmitted as soon as you are connected to the World Wide Web.

3. Google drive connecting with the Google search engine more deeply: Because Google owns producers, Drive and Search Engine, It becomes to find a file, via Google Drive, more easily than the rest of the other services that offer cloud storage, of course, this requirement applies to appear the licensed public files and not private files.

4. The use of technique image recognition: Google uses image recognition technique in Google Drive application, in image files, which makes the search for an image or a person; it is very easy via the Google Drive cloud service.

Eighth: - Upload files (Books or thesis) as requested by the beneficiaries to digital warehouse. As shown in Figures No. (6) and No. (7) and No.(8) and No. (9) in the Appendix (1). Now it has been uploaded file into the digital warehouse as shown its name in the digital warehouse. As shown in Figures No. (10) and No. (11) in the Appendix (1).

Ninth: - Create a link to the file uploaded, by clicking on the Get shareable link button, and copy the link, by Clicking on the Copy link button. Or by clicking the right mouse button and then choose to Get shareable link option. As shown in Figure (12) in Appendix (1).

And then we are pressing a sharing settings button. As shown in Figure (13) in Appendix (1). And then we are pressing a copy link button from in Figure (13) to take a copy of the link to the clipboard. As shown in Figure (14) in Appendix (1).

Then clicking the done button to complete the process of copying the link and the closure of the copy link windows.
Tenth: - Availability of digital resources on social media to know the beneficiary and benefit from the resources according to his request, according to his interests, we open the Facebook page for the library and then Creation of a group and we are writing group name that established. As shown in Figure (15) in Appendix (1).

Then paste the link that existed in clipboard established previously to Facebook group page. As shown in Figures No. (6) and No. (16) and No.(17) and No. (18) in the Appendix (1).

In Figure (18) in Appendix (1). Shows it beneficiaries interaction with selective transmission information service.

\section{The fourthSection \\ Results and Recommendations} (4.1) The results:-

The Research used an applied approach to apply selective dissemination of information service and cloud computing technology to build a digital warehouse by using the Google drive.It uses Facebook as a media to inform beneficiaries of the digital resources available at the Central Library of the Iraqia University that meet their demands. The research has come to a number of conclusions the most important:-

1. It is applying selective dissemination of information service provides time for beneficiaries of the university libraries to retrieve the intellectual works in the topics they care about quickly and easily.

2. The use of cloud computing applications In university libraries establishes a digital warehouse and saves all digital sources from damage or loss because the digital data are kept in more than one place in the world and therefore there is that they may be damage or loss;

3.The use of cloud computing applications in university libraries leads to electronic storage and retrieval which helps to speed the retrieval of digital resources.

1. It is applying selective dissemination of information service provides time for beneficiaries of the university libraries to retrieve the intellectual works in the topics they care about quickly and easily; 
2. The use of cloud computing applications In university libraries establishes a digital warehouse and saves all digital sources from damage or loss because the digital data are kept in more than one place in the world

3. The use of cloud computing applications in university libraries leads to electronic storage and retrieval which helps to speed the retrieval of digital resources.

4. The use of social media in the provision of information services for university libraries, it is working to increase the interaction between the University Library and beneficiaries.

5. The use of the digital and electronic means, it works to offer information services for university libraries over the twenty-four hours, rather than abide by the official working hours and without the need to enter the library and benefit from its services.

6. The offer of information services in computerized form, it works seriously interaction and cooperation between the Iraqi university libraries.

7. The exclusion of the beneficiary for technical problems or maintenance and development of the system.

8. Take advantage of the high specifications of remote device in the cloud.

9. Utilization of large servers in complex operations may require highspecification devices.

\section{(4.2) The recommendations:-}

The study unearthed a number of recommendations the most important points of which are the following.

1. Advocating awareness of the importance of cloud computing and working on developing human resources to deal with this technique. This will achieve the optimal use of these services which require us to understand well the dimensions of this modern technology;
2. The cloud computing will change the format of services offered by the university libraries, and therefore it must contribute technological developments from the beginning without being late. We should absorb its importance and its active role especially at the present time.

3. University libraries need to be encouraged to provide computerized information services (selective dissemination of information service), and to convert the resources from of the paper form (Hard copy) to digital form (software copy). That means to convert from traditional form to digital one.

4. Urged university libraries on investing cloud computing application that create digital warehouse and save the digital resources from damage and loss and take advantage of its in the process of storage and electronic retrieval.

5. The cloud computing techniques will help libraries in cost savings and providing new services, where the computerization aimed at applying the principle of payment after use, which contributes significantly to the cost savings with the use of latest applications and latest advanced management tools.

6. The provision of internet lines permanently in university libraries and the Internet will be of high quality and speed.

7. Training of staff in university libraries and their participation in training courses to offer computerized information services.

8. The provision of devices and equipment necessary from scanners and digital cameras to convert resources from of the paper form (Hard paper) form to digital form (software copy).

9. The provision of a website for the General Secretariat of the Central Library in the Iraqia University. 


\section{References:}

1.

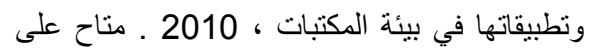
الموقع https://www.slideshare.net/Muawwad/ss $-14361956$

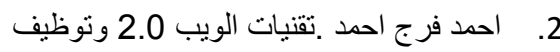

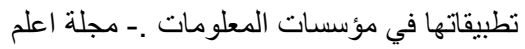

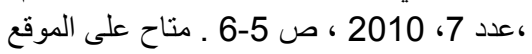
file://C:/Users/ahmed/Downloads/2.0. 2018/3/3 تاريخ الاطلاع pdf

الاكلبي ، علي بن ذيب . تطبيقات الويب الدلالي في بيئة

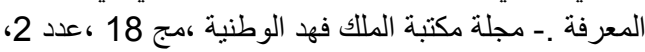

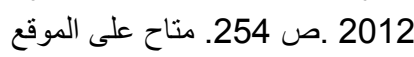
http://www.kfnl.org.sa/Ar/mediacenter/EMagazi ne/DocLib/\%D8\%A7\%D9\%84\%D8\%AB\%D8\% A7\%D9\%85\%D9\%86\%20\%D8\%B9\%D8\%B4\%

D8\%B1/249-260.pdf.2018/3/3 تاريخ الاطلاع 3. صباح محمد كلو . الحوسبة السحابية :مفهومها وتطبيقاتها في مجال المكتبات ومر اكز المعلومات.

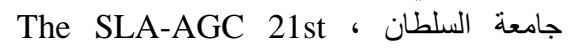
صناح على الموقع. Annual Conference http://www.qscience.com/doi/pdf/10.53 .39/qproc.2015.gsla.8 الموسوعة الحرة ويكيبيديا متح على الرابط https://ar.wikipedia.org/wiki/\%D8\%AA \%D8\%AE\%D8\%B2\%D9\%8A\%D9\%86 \%D8\%B3\%D8\%AD\%D8\%A7\%D8\%

2018/3/5. A8\%D9\%8A Abu Dhabi, United Arab Emirates, 17-

19 March 2015

العليمي. ثروت العليميالمرسي. سبل الافادة من

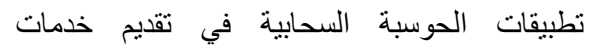

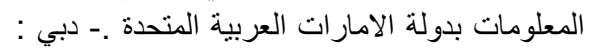
كلية الدراسات الاسلامية ، The SLA-AGC 20th Annual ConferenceDoha, Qatar, الموقع 2014 20

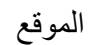
http://www.qscience.com/doi/pdf/10.53 39/qproc.2014.gsla.6 أحمد ماهر خفاجة .الحوسبة السحابية وتطبيقاتها في مجال المكتبات - Cybrarians Journal. -. عدد

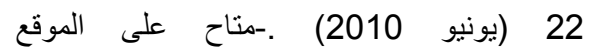
http://www.journal.cybrarians.org/index .php?option=com_content $\&$ view=article \&id=445:2011-08-10-01-3653\&catid=158:2009-05-20-09-59-42 تاريخ الاطلاع 2015/12/5.
Kasturi S. Mate. Use of Cloud Computing in Library Services. College Librarian 9. محد شوقي شلتوت .الحوسبة السحابية بين الفهر والتطبيق .مجلة التعليم الالكتروني ،ع 10 10-2015.

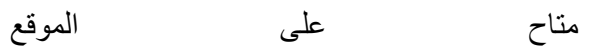
http://emag.mans.edu.eg/index.php?pag e=news\&task=show\&id=365 الاطلاع 1016/6/5.

10. البياتي ، عمار. الحوسبة السحابية ـ مجلة الرائد

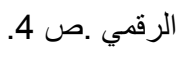

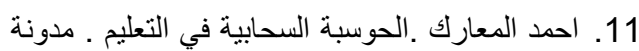

خاصة بمقرر (577 نهج) في برنامج الماجستير .

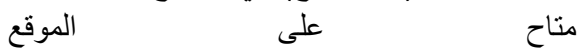
https://almaarik.wordpress.com/\%D8\% A7\%D9\%84\%D8\%AD\%D9\%88\%D8\% B3\%D8\%A8\%D8\%A9$\% \mathrm{D} 8 \% \mathrm{~A} 7 \% \mathrm{D} 9 \% 84 \% \mathrm{D} 8 \% \mathrm{~B} 3 \% \mathrm{D} 8 \% \mathrm{~A}$ D\%D8\%A7\%D8\%A8\%D9\%8A\%D8\% A9-\%D9\%81\%D9\%8A\%D8\%A7\% $9 \% 84 \% \mathrm{D} 8 \% \mathrm{AA} \% \mathrm{D} 8 \% \mathrm{~B}$ 9\%D9\%84\%D9\%8A\%D9\%85-cloud/computing-in-education 2017/11/10

12. تيسير اندراوس سليم .الحوسبة السحابية بين النظرية والتطبيق .- الاردن :جامعة البلقاء . cybrarians journal, 13. المعراوي ،انس. ماهي الحوسبة السحابية مبادىء

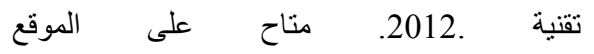
http://ardroid.com/2012/10/24/what-iscloud-computing/ 2015/12/5

14. Al Morsy, Mohamed .John Grundy and Ingo Müller. An Analysis of the Cloud Computing Security Problem.- Computer Science \& Software Engineering, Faculty of Information \& Communication Technologies.Swinburne University of Technology, Hawthorn, Victoria, Australia.p2.

15. سامي احمد شناوي ،محمد خليل عباس . استخدام

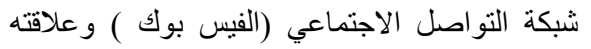

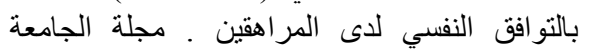

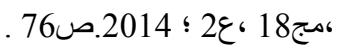

16. الطيار فهد بن علي.شبكات التواصل الاجن التماعي

و اثرها على القيم لدى طلاب الجامعة (تويتر نموذجات التئ

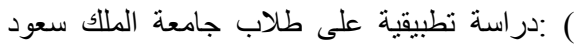

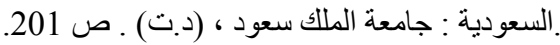




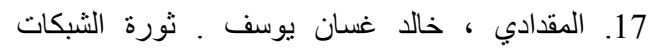

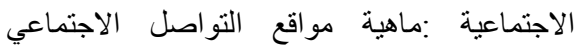

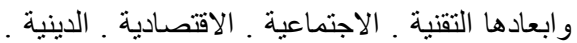

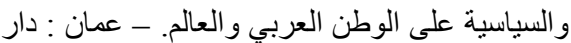

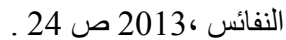
18. الاتحاد الاوربي .استخدام وسائل التو اصل الاجتماعي

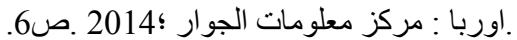

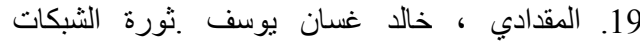
الاجتماعية .مصدر سابق .ص 26. 20. الاتحاد الاوربي. استخدام وسائل التو اصل الاجتماعي مئي

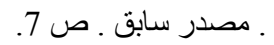

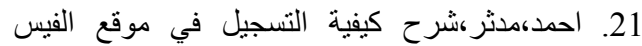

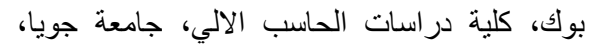

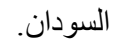

22. سامي احمد شناوي ، محمد خليل عباس .استخدام

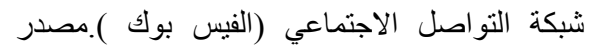

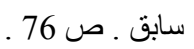

23. محمد محمد امان. خدمات المعلومات مع الشارة

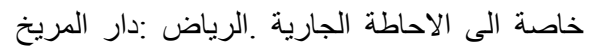

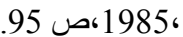

24. عبد الستار شاكر. خدمات المعلومات المحوسبة في

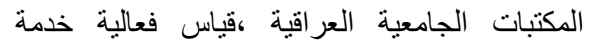
الاحاطة الجارية المحوسبة وخدمة البث الانتبائي المئي

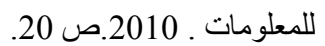
25. محمد محمد امان ـ خدمات المعلومات .مصدر سابق صمات (20)

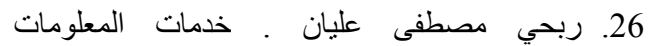
. information services.: للنشر و التوزيع ، 2010 ـ 357.

\section{Appendix (1)}

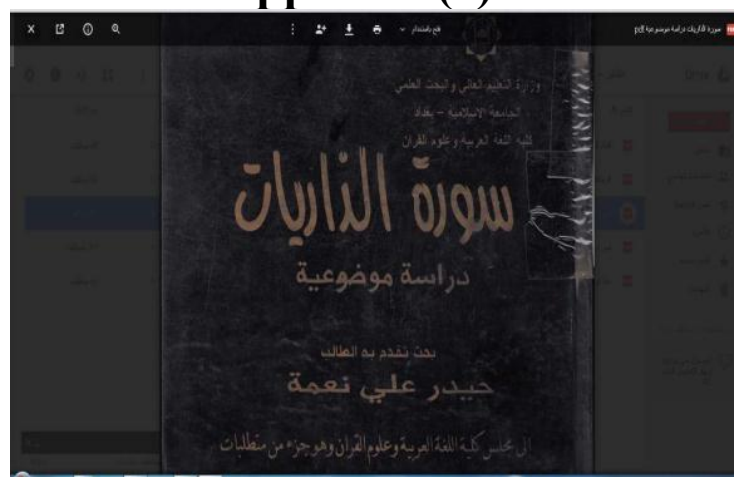

Figure (1) converting the source of the paper (hard copy) to digital.

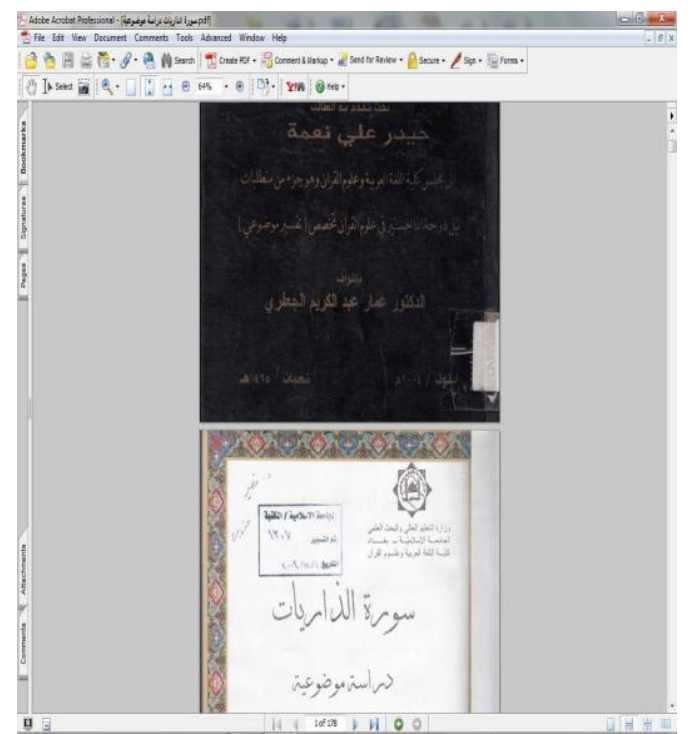

Figure (2) assemble the format (pdf).

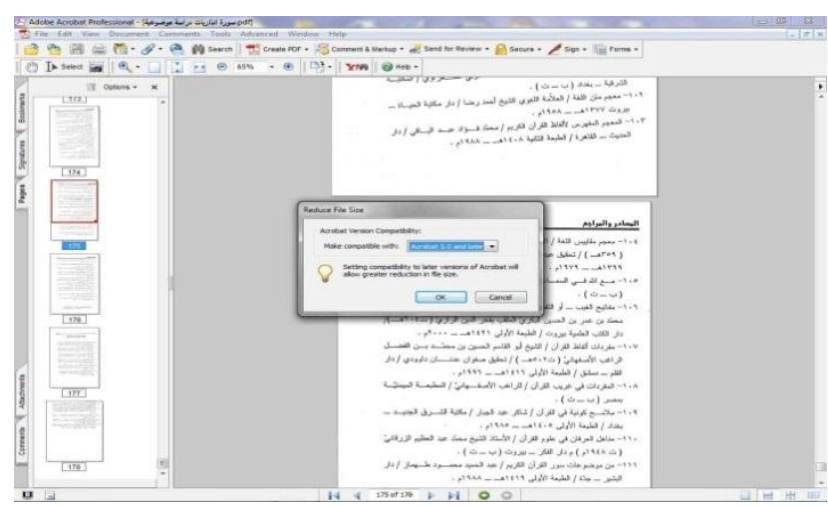

Figure (3) illustrates the file compression. 


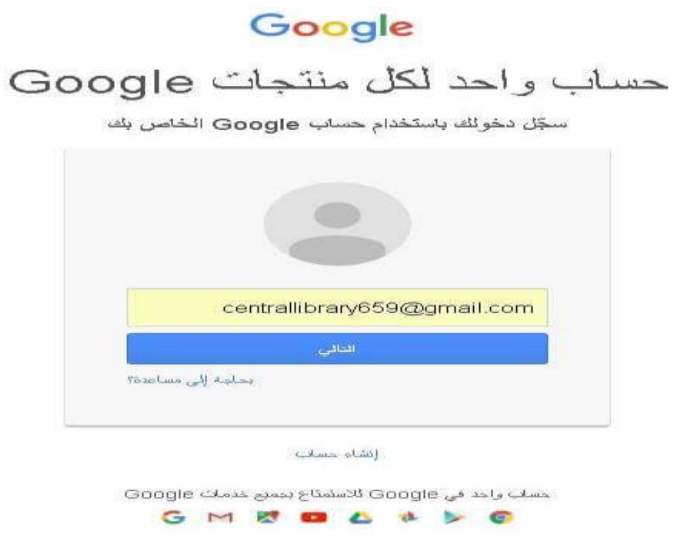

Figure( 4) illustrates the way in which open e-mail.

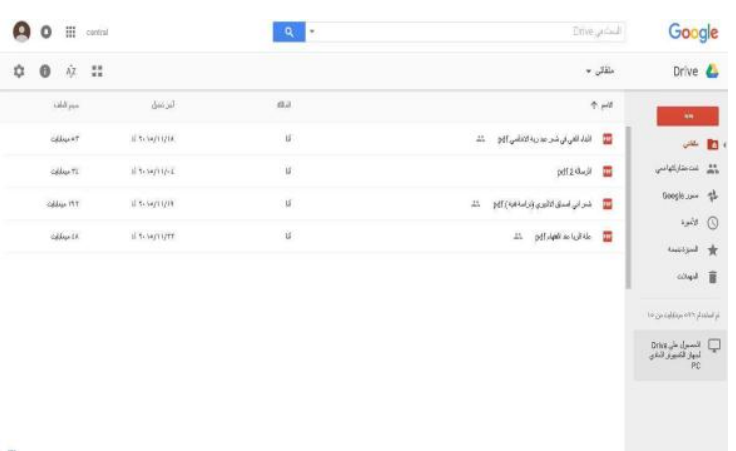

Figure (5) illustrates the digital warehouse.

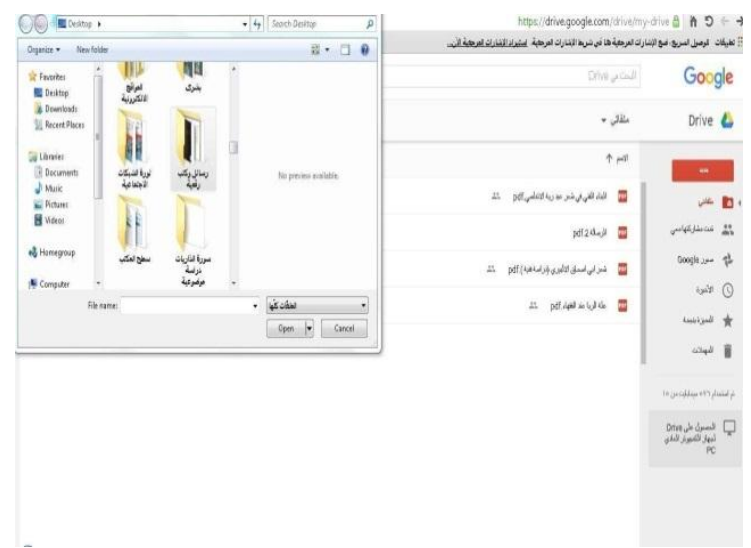

Figure( 6) shows how the lifting of the sources of digital information (upload file).

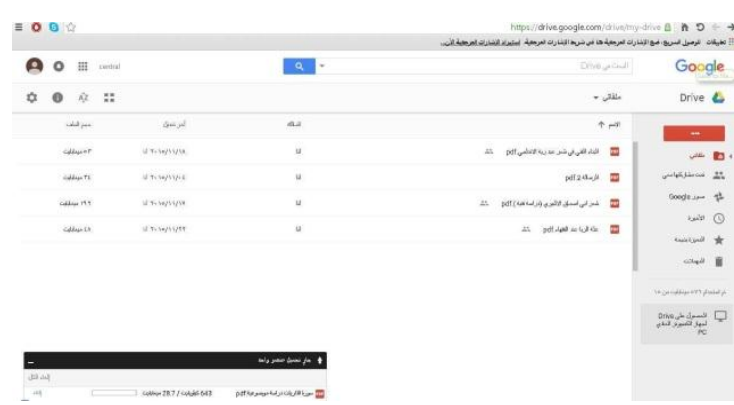

Figure ( 7) illustrates the upload file

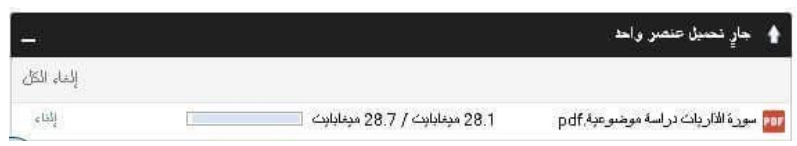

Figure (8) shows the path upload the source (enlarged image).

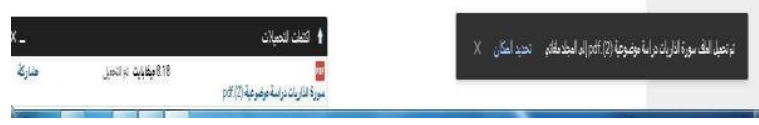

Form (9) shows the completion of the upload.

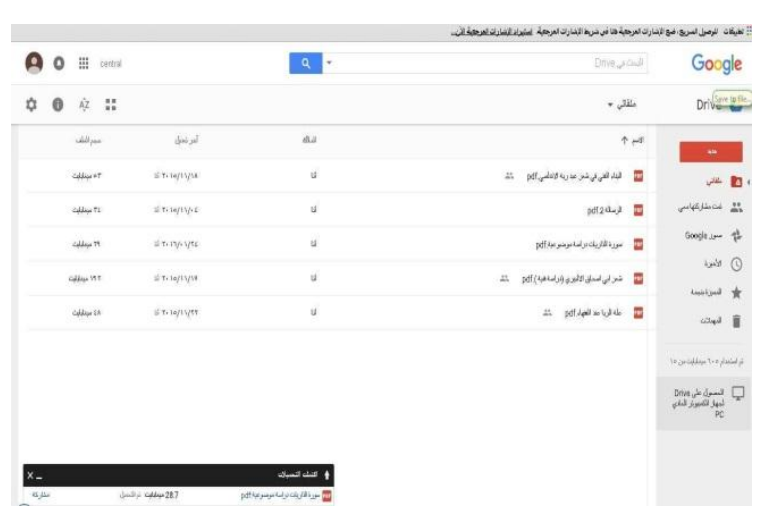

Figure (10) illustrates Digital Warehouse with file upload.
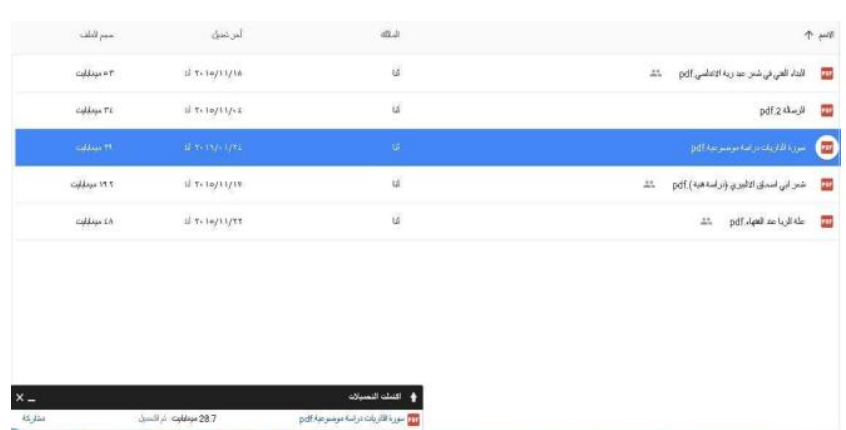

Figure (11) illustrates Digital Warehouse with file upload (enlarged image). 


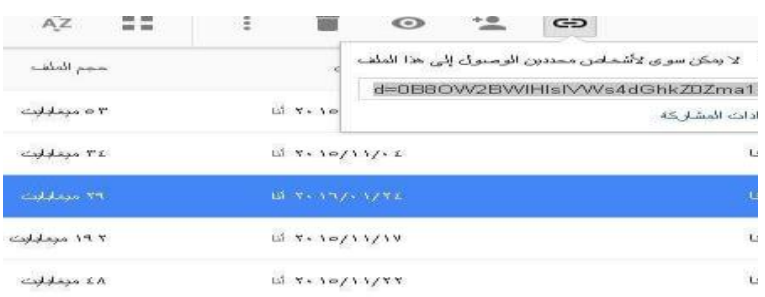

Figure (12) explain how to create a link..

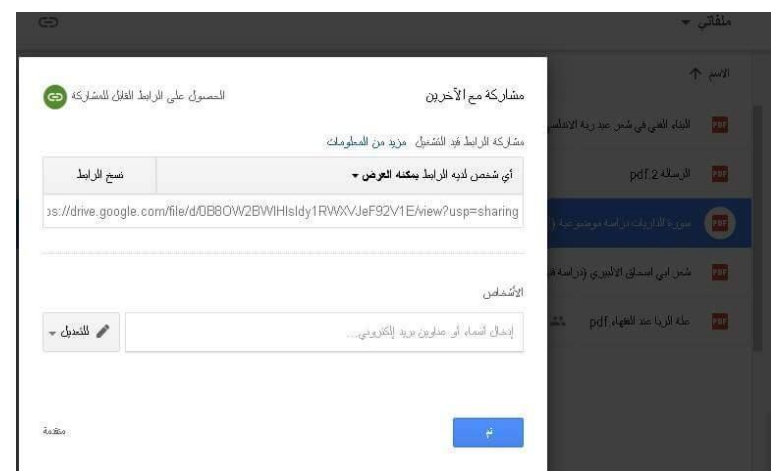

Figure (13) illustrates the settings of your participation.

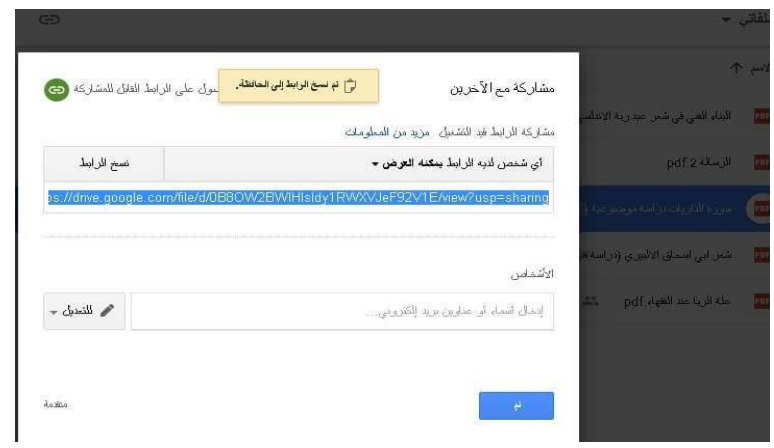

Figure (14) illustrates the link copied to clipboard.

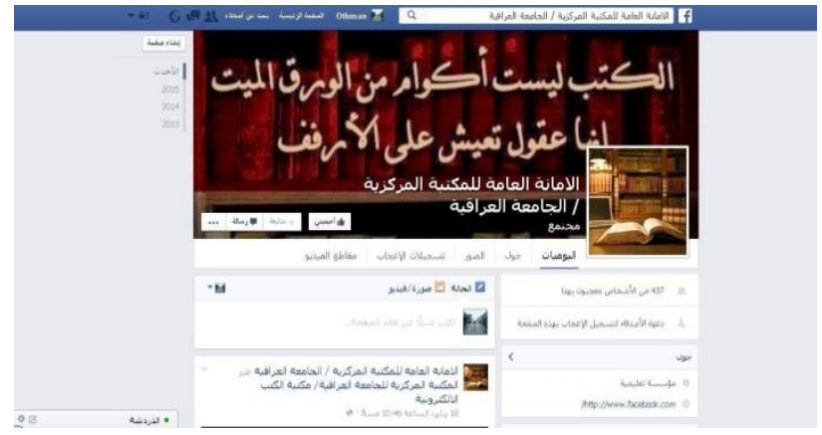

Figure (15) shows the group page on Facebook .

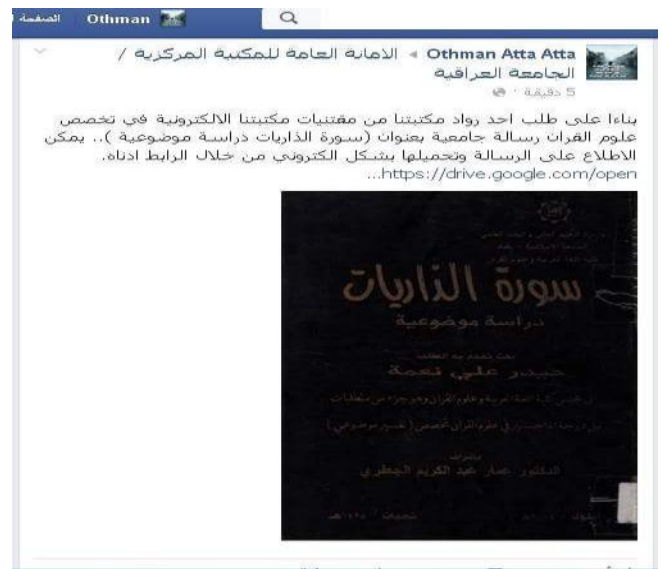

Figure ( 16) shows the Paste Link the group page on Facebook.

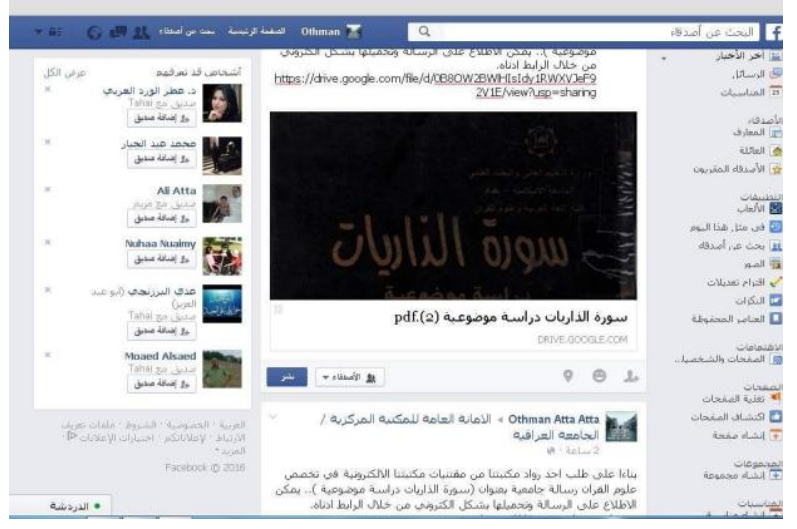

Figure( 17) shows the source publication in

Facebook Page. 


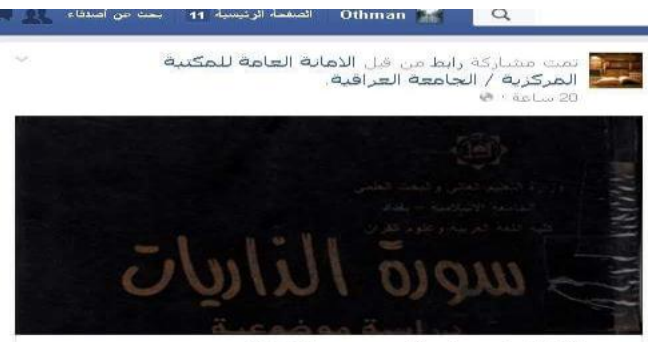

سورة الذاريات دراسة موضوعية (2). سورة

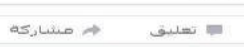

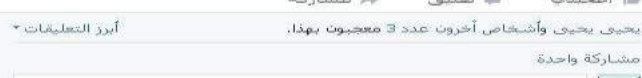
P.:4 年

Figure (18) illustrates the beneficiaries interact with the broadcast selective information service.

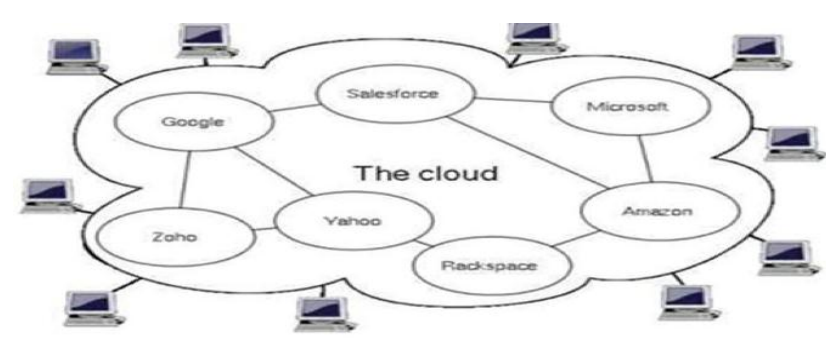

Figure (19) show cloud computing infrastructure.

\section{الخزن السحابي: الحوسبة السحابية و مواقع التواصل الاجتماعي لاستخدام خدمة البث

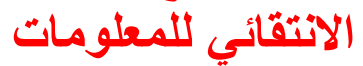 عثمان عطا اسماعيل الامانة العامة للمكتبة المركزية

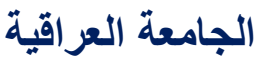

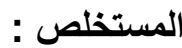

تهـدف الدر اســة باســتثـار الحوسـبة الســحابية وتقنياتهــا ومواقـع التو اصـل الاجتمــاعي فـي تقـديم خدمــة

البــث الانتقـائي للمعلومــات لمجتمـع البـاحثين و المسـتقيدين، و التعـرف علـى مفهـوم الحوسـبة الســابية ومميز اتهـا

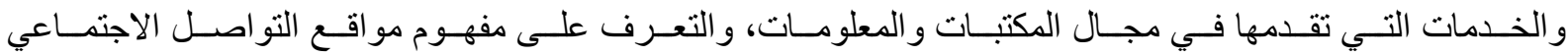
فضــلا عـن عمـل مســودع رقمـي و اتاحسة رابـط الكتـب الرقميـة علـى مواقـع التو اصـل الاجتمــاعي خدمـة للبـاحثين و المستفيدين وتلبية طلباتهم وحاجاتهم.

الكلمات المفتاحية: - الحوسبة السحابية، مواقع التو اصل الاجتماعية، تكنولوجيا المعلومات، خدمة البث الانتاقئي

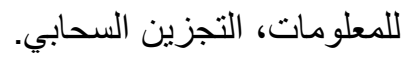

